\title{
Assessing the Effectiveness of Rice Procurement Programme and Farmers' Profitability in some Selected Areas of Bangladesh
}

\begin{abstract}
MS Rahaman ${ }^{1 *}$, M A R Sarkar ${ }^{1}$, M J Kabir ${ }^{1}$, L Deb ${ }^{1}$, M C Rahman ${ }^{1}$, M A Islam ${ }^{1}$ and M A B Siddique ${ }^{2}$
ABSTRACT

Using cross-sectional data obtained through carrying out a sample survey conducted during 2018, we examined the perception of farmers and millers about the paddy and rice procurement system and its feasibility. A probit model was employed to ascertain the factors influencing the likelihood of participating in the procurement system by farmers from two districts of Bangladesh. The results showed that the government procurement system has significant impacts on both the participant farmers and millers. The farmers and millers' net profit was TK 4,205 and TK 3,930 by selling a ton of paddy and cleaned rice, respectively, to the procurement center rather than in the local market. The probit regression analysis revealed nine different factors that significantly influenced farmers' participation in the paddy procurement programme. Results further implied that educated farmers had procurement cards with sufficient system knowledge, residing near the hub with improved road access, and association with political parties get preference in participating in the programme. The findings also indicate that lucrative prices, programme scheduling and good conduct of procurement employees inspire farmers to participate in the programme. The government procurement programme has several drawbacks such as anomalies in selecting farmers, taking extra paddy by the employees, corruption, unsuitable payment system, and procurement capacity. Therefore, the government would be vigilant to ensure that the procurement system will provide farmers with price support. A well-functioning procurement system is crucial for guaranteeing the country's food security by ensuring a fair price for the producers. Finally, the study proposed some policy guidelines based on the findings to establish a sound paddy and/or rice procurement system in Bangladesh.
\end{abstract}

Key words: Food security, procurement, factors affecting, profitability, probit model

\section{INTRODUCTION}

Bangladesh is on the verge of commercial agriculture and, in the face of rapid population growth. It is urgently trying to increase agricultural production where food security and livelihood depend heavily on agriculture and agricultural products. Therefore, the Bangladesh government is steadily pursuing agricultural policies to sustain food selfsufficiency and enhance the farmers' financial condition towards achieving the target of sustainable development goals (SDG). In Bangladesh, rice production dominates the agricultural sector by covering about 75 percent area and contributing in the national economy about 4.5 percent of total gross domestic product (BBS, 2018; BER, 2018).
During 2018-19, about 77 percent of the total cropped area was covered by rice when the entire production reached 36.39 million tons, which enabled a surplus of 4.2 million tons (BBS, 2019; MoA, 2019). As rice is synonymous with food in the country, sustaining its production will lead the country to achieve food security.

On the other hand, with the increased rice production, there are wider price fluctuations at the harvesting and immediately after the harvesting period, making the price level of the food market unstable and volatile. Besides, the price hike of rice at the downstream part of the supply chain has imperative implications on consumption and nutritional intake, especially on low-income consumers of Bangladesh. As a

\footnotetext{
${ }^{1}$ Agricultural Economics Division, Bangladesh Rice Research Institute, Gazipur 1701, Bangladesh, ${ }^{2}$ Director (Administration and Common Service), Bangladesh Rice Research Institute, Gazipur 1701, Bangladesh.

${ }^{*}$ Corresponding author's E-mail: saju021@gmail.com (M S Rahaman)
} 
whole, this group of the population spend their large share of the budget on food purposes. Furthermore, it's a major challenge of the government to balance the interest of producers and consumers. To tackle this problem, the government of Bangladesh formulated a food procurement policy to ensure an encouraging price for the producer, maintain food security, and continue supply in the government food distribution system.

The foodgrain procurement system in Bangladesh has a long history. After the introduction of the public food marketing system, the government's food department running the rice procurement campaign to procure rice from the producer. In the sixties, large farmers were involved in the irregular supply of rice at a fixed price normally set by the then government (Ahmed, 1989). In the nineties, the Food Ministry relied on millers for the procurement of paddy and rice. The millers imposed a fixed commission on paddy purchasing from the farmers at the government price and milling the paddy. For a long time, the procurement programme's primary goal was to ensure adequate foodgrains for the public food distribution system (PFDS). From the nineties and onwards, PFDS and price support have become essential for the procurement programme.

The price support worked to ensure a floor price that was declared just before the harvest season, but recently, the scheme has been structured to guarantee farmers an incentive price. The procurement price is now solely related to food grain production costs and declared during the planting season. The current procurement process is said to be inefficient in providing opportunities to the farmers (Rahman et al., 2020). Earlier studies such as Dorosh and Shahabuddin (2002) investigated procurement prices in four years, three of which experienced extremely high procurement rates in Boro season. This resulted in higher government costs and windfall income for those who were fortunate enough to sell at the procurement centers. There are also claims that procurement centers often refuse to buy from farmers and collude with millers and intermediaries (Shahabuddin and Islam 1999; Shahabuddin et al. 2009). Reza (2001) also assessed the government's Boro procurement programme and showed the efficiency of the Boro procurement scheme, compared Boro paddy market price and procurement price for several years, analyzed the factors involved in the farmers, millers and trader's involvement in the Boro procurement programme. In cases between selling rice to procurement centers and selling rice on the market, the study found substantial differences in net returns for farmers and millers. Deb (2008), in his study, showed that there is a fair balance between producer and customer interest in the government procurement programme. Shahabuddin et al. (2009) evaluated the efficacy of the domestic procurement system, primarily in terms of farmers' involvement in both the paddy and rice procurement process. Sattar (2011) analyzed the structure and functions of Bangladesh's public food operations, showing the efficiency of the paddy and rice procurement systems. Alam et al. (2015) found rising annual household income from the farmers who participated in the programme and noted that government stock and market prices were negatively associated with rice procurement. Alam et al. (2017) also examined the effectiveness of Boro rice procurement in the Jamalpur district and showed that small and medium-sized farmers' participation was negligible and largely dominated by the politicians. A recent study (Alam et al., 2020) evaluated farm-level stock of rice and the effectiveness of the procurement system. The findings indicated that stocks at the farm level differ positively with growth, and the government stock was negatively correlated with domestic procurement, but the expected delivery was positively correlated with that. 
This also indicates that the farmer's annual income has risen due to participating in the procurement programme.

Even though many previous studies focused on the same issue in various locations, they are reviewed to have many sorts of limitations and implemented in different manners. To consider the requirement of policymakers, the present study is a pragmatic attempt to assess the effectiveness of the procurement programme with clear objectives of analyzing the farmers and miller's profitability in Boro season; farmer's and miller's perception of the procurement system; perceived constraints related to the procurement programme and the drivers responsible for the farmers participation of the government procurement programme. This research would be useful in deciding if the farmers are pleased or unhappy with the Boro paddy procurement of government. If the farmers are satisfied with the paddy procurement programme, in that case, the present analysis will help evaluate the procurement system's efficacy and figuring out the problems, at least in the study region. The study findings would also be helpful for producers, traders, millers and procurement officials, and policymakers in upgrading the government procurement mechanism.

\section{METHODOLOGY}

\section{Study area}

This study was carried out in two districts of Bangladesh, namely Naogaon and Mymensingh. The study locations were selected purposively based on the surplus in rice production and intensity of welldeveloped rice mills in the areas. For this study, primary data were collected through carrying out a farm-level survey during MayAugust 2018.

\section{Sampling procedure and method of data collection}

A questionnaire was designed to include open-ended and closed-ended questions for exploring quantitative and qualitative information. A random sampling technique was applied to draw representative samples for this study. The participant farmers and millers were selected from the procurement participants list of Local Storage Depot (LSD) of respected upazila. Non-participant farmers were selected from a comprehensive farmers list collected from the upazila Agriculture Office of concerned upazila. Finally, 250 respondents, out of which 20 millers, 50 participant farmers, and 55 nonparticipant farmers, were drawn from each district using the random sampling technique (Table 1).

Pre-testing has been performed prior to the final data collection to ensure a sound and effective interview programme. Several inaccuracies were found, and subsequently, some adjustments were made to improve the questionnaire. The researchers reviewed inconsistencies and expressions of undue interest in the findings were reviewed. For analysis, the variables and their forms have been labelled appropriately.

Table 1. Sampling frame.

\begin{tabular}{|c|c|c|c|c|c|}
\hline \multirow[b]{2}{*}{ District } & \multirow[b]{2}{*}{ Upazila } & \multicolumn{3}{|c|}{ Sample category and size } & \multirow[b]{2}{*}{$\begin{array}{r}\text { Total } \\
\text { sample }\end{array}$} \\
\hline & & Millers & $\begin{array}{l}\text { Participant } \\
\text { farmers }\end{array}$ & $\begin{array}{c}\text { Non-participant } \\
\text { farmers }\end{array}$ & \\
\hline Naogaon & Mohadebpur and Sadar & 20 & 50 & 55 & 125 \\
\hline Mymensingh & Muktagacha and Sadar & 20 & 50 & 55 & 125 \\
\hline & Total & 40 & 100 & 110 & 250 \\
\hline
\end{tabular}




\section{Data analysis and model specifications}

Both descriptive and inferential statistics were used in analyzing the data. Average, percentage and differences were the primary descriptive statistical tools employed to show the results comprehensively. The Likert type five scale was used to assess farmers' and millers' perceptions about the paddy and rice procurement system. The collected data were analyzed using Microsoft Excel 2016 and STATA 16.

We aimed to determine socio-economic and demographic variables influencing farmers' willingness to participate in the rice procurement programme through this research. A qualitative response model is appropriate for the farmers' dichotomous nature because the response model relates the probability of an event to various independent variables. The model is also helpful when determining the respondents' characteristics associated with their decisions (Uzunoz and Akcay, 2012). To provide a detailed analysis of the government procurement programme's participation decision, we applied a discrete choice probit model for binary responses (yes, no). Probit analysis is based on the cumulative normal probability distribution. The binary dependent variable takes on the values of zero and one (Aldrich and Nelson 1984). Therefore, the probit analysis can provide statistically significant results to identify the factors influencing the probability of participation in the rice procurement programme.

In the binary probit model, farmers who participated in the procurement programme was taken as 1 , while not participated as 0 . The $i^{\prime}$ th farmers are presumed to achieve maximum profit, i.e. preference to enrol in the procurement programme rather than not to participate in the programme. The probability $p_{i}$ of choosing any alternative over not choosing it can be expressed as in (1), where $\phi$ represents the cumulative distribution of a standard normal random variable (Greene, 2011):

$p_{i}=\operatorname{prob}\left[Y_{i}=1 \mid X\right]=\int_{-\infty}^{x_{i}^{\prime} \beta}(2 \pi)^{-\frac{1}{2}} \exp \left(-\frac{t^{2}}{2}\right) d t$

$=\Phi\left(x_{i}^{\prime} \beta\right)$

The relationship between a specific variable and the probability outcome is interpreted employing the marginal effect, which accounts for the partial change in the probability. The marginal effect associated with continuous explanatory variables $X k$ on the probability $P(Y i=1 \mid X)$, holding the other variables constant, can be derived as follows (Greene, 2011):

$\frac{\partial P i}{\partial x_{i k}}=\phi\left(x_{i}^{\prime} \beta\right) \beta_{k}$

where $\phi$ represents the probability density function of a standard normal variable. The marginal effect on dummy variables should be estimated differently from continuous variables. Discrete changes in the predicted probabilities constitute an alternative to the marginal effect when evaluating a dummy variable's influence. Such an effect can be derived from the following (Greene, 2011):

$\Delta=\Phi(\bar{x} \beta, d=1)-\Phi(\bar{x} \beta, d=0)$

The marginal effects provide insights into how the explanatory variables shift the probability of participation in the procurement programme. Using the econometric software, marginal effects were calculated for each variable.

Factors influencing farmers' attitudes towards participation in the procurement programme may include procurement structure, price, and farmers' social demographic and possible interaction between these factors (Alam et al., 2015). In this paper, we assume that the farmers' socioeconomic and demographic characteristics affected their participation in the procurement programme. The characteristics such as farmers' age, education, knowledge about procurement, their marketed surplus, distance from home to the local 
market, distance from home to procurement center, communication system (nature of the road), procurement price, having procurement card, appropriate procurement time, manner of officials in the procurement center, presence of corruption, and political affiliation were handled as explanatory variables. Therefore, we treated the variables in the model, which were considered to be statistically significant. Data in Table 2 show the definition of variables and their mean values.

\section{RESULTS AND DISCUSSION}

\section{Procurement system}

The procurement programme is the only and well-known system for the government or official food grain stock in Bangladesh. Through this system the government, (a) provides humanitarian help during natural disasters, (b) ensures food security by the distribution of food to low-income families, and (c) sustains steady market prices when necessary. The process of collecting, storing, and supplying food grains is costly (Shahabuddin and Shahana, 2014). The ministry of food (MoF) decides the procurement price and the period of procurement. Government procurement centers situated in the country's different areas purchase paddy directly from the farmers and rice from the mill (Rahman et al., 2020). According to the internal food grain collecting policy, all types of farmers have the opportunity to sell paddy at the procurement center, following the government's strict grain standard, and a farmer can sell $120 \mathrm{~kg}$ to 3 tons of paddy in a season based on the size of the farm (MoF, 2017). On the other side, millers supplied a set amount of rice, as determined by the government based on their milling ability. The procurement personnel provide weight, price, and stock certificates (WPSC) depending on the characteristics and

Table 2. Summary of the variables used in executing the probit regression analysis.

\begin{tabular}{llc}
\hline Variable & Definition & Mean value \\
\hline $\begin{array}{l}\text { Dependent variable } \\
\text { Farmer's participation in the } \\
\text { procurement programme }\end{array}$ & Dummy: 1 = If participant, $0=$ otherwise & 0.48 \\
$\begin{array}{l}\text { Independent variable } \\
\text { Farmer's age }\end{array}$ & Years & 48.71 \\
Education & Years of schooling & 4.15 \\
Knowledge about the procurement & Scored (between 1 - 5) & 2.52 \\
system & Amount of paddy in Kilogram $(\mathrm{kg})$ & 4836 \\
Marketed surplus & Dummy of the idea about price: $1=$ if more, $0=$ otherwise & 0.57 \\
Procurement price & Dummy: $1=$ having a procurement card, $0=$ otherwise & 0.69 \\
Procurement card & Dummy: $1=$ for the appropriate time of procurement, $0=$ & 0.29 \\
Procurement time & otherwise & \\
Distance to local market & Kilometer $(\mathrm{km})$ & 7.35 \\
Distance to procurement center & Kilometer $(\mathrm{km})$ & 15.93 \\
Communication system & Dummy: $1=$ for good connectivity, $0=$ otherwise & 0.55 \\
Political affiliation & Dummy: $1=$ political affiliation influences selling paddy, $0=$ & 0.71 \\
Manner of officials & otherwise & \\
Corruption in the system & Dummy: $1=$ if well, $0=$ otherwise & 0.60 \\
\hline
\end{tabular}

Source: Analyzed and prepared by the authors' based on the data from the field survey. 
make payments to the farmers and millers through banking transactions.

The government aims to reach the procurement target each year, but it has been procuring less than the target for a long time. In Boro season, only 52 and 91 percent of the targeted procurement paddy and rice were met during 1996-2010 (Alam et al., 2015; Sattar, 2011). A disappointing scenario has been observed in Aman procurement, while in the case of Boro procurement, the status is much better. The success of the procurement programme is the achievement of its target (to what extent the new procurement mechanism helps the government to obtain sufficient supplies for its distribution needs); it has been observed that a total of 71 percent of the country's rice procurement has been off-taken domestically (Alam et al., 2015). There are also variations in the rate at which paddy and rice procurement targets are achieved in terms of the goal and real fulfillment of procurement amounts. The cause for this gap could be the lack of knowledge and information, the communication between procurement officials and farmers or millers, the lack of accountability of procurement officers, etc.

\section{Socio-economic and demographic characteristics of rice farmers and millers}

Table 3 depicts the socio-economic and demographic profiles of sampled millers and farmers. The average age was found 50 years for millers and 48 years for both participants and non-participants farmers. Approximately 55.00, 54.00, and 57.27 percent of millers, participants and non-participants farmers respectively, were between 21 and 50 years of age, while $45.00,46.00$ and 42.73 percent of the millers, participants, and non-participants farmers respectively were older than 51 years of age. Farmers age plays a crucial function in farming, management practices, and the adoption of modern methods. Many researchers suggest older farmers are more veteran and more familiar with farming processes, capable of handling their inputs more effectively and risk-averting than their younger counterparts. Some researchers claim younger farmers are adopting modern procurement programmes quicker than their older peers, but we haven't seen any substantial gap.

The average household sizes were 4.58 , 5.00 , and 5.25 for the millers, participants, and non-participant farmers, respectively, which is a bit higher than the average household size (4.50 people) of Bangladesh (HIES, 2016). Farmers' education is also a significant consideration responsible for the success of the government procurement programme. A qualified farmer is capable of collecting up-todate market information and allows to make a smarter participation decision, which has a positive effect on the procurement programme. Educational attainment was classified into five categories. About 22.00 and 45.45 percent of the participant and nonparticipant farmers were illiterate. Most of the participants (77 percent) and non-participant (51.82 percent) farmers were primary to higher secondary level educated. On the other side, 75 percent and 25 percent millers were primary to higher secondary level and graduate-level educated, respectively.

The surveyed participant farmers and non-participant farmers had an average farm size of 3.87 acres and 2.01 acres, respectively. About 24, 67, and 9 percent of participants were small, medium and large farmers, respectively. Whereas about $72.73,21.82$ and 5.45 percent of the non-participants were small, medium and large farmers, respectively. Farming is the primary occupation of the 73 percent participant farmers and 81 percent non-participants farmers.

About 15, 72, and 13 percent participant farmers' household annual earning were TK. 50000-100000, TK 100001-250000, and TK 250001 
Table 3. Socio-economic and demographic features of the respondents.

\begin{tabular}{|c|c|c|c|}
\hline Particular & Miller & $\begin{array}{l}\text { Participant } \\
\text { farmer }\end{array}$ & $\begin{array}{l}\text { Non-participant } \\
\text { farmer }\end{array}$ \\
\hline \multicolumn{4}{|l|}{ Age (\%) } \\
\hline $21-30$ years & 7.50 & 4.00 & 3.64 \\
\hline $31-40$ years & 17.50 & 25.00 & 25.45 \\
\hline $41-50$ years & 30.00 & 21.00 & 28.18 \\
\hline 51 and above & 45.00 & 46.00 & 42.73 \\
\hline \multicolumn{4}{|l|}{ Family size (\%) } \\
\hline 1-3 person & 12.50 & 7.00 & 6.00 \\
\hline 4-5 person & 62.50 & 59.00 & 57.00 \\
\hline 6 and above person & 25.50 & 34.00 & 37.00 \\
\hline \multicolumn{4}{|l|}{ Education (\%) } \\
\hline Illiterate $(0)$ & - & 22.00 & 45.45 \\
\hline Primary(i-v) & 12.50 & 36.00 & 36.36 \\
\hline Secondary(vi-x) & 25.00 & 26.00 & 9.09 \\
\hline Higher secondary(xi-xii) & 37.50 & 12.00 & 6.37 \\
\hline Graduate and above & 25.00 & 4.00 & 2.73 \\
\hline \multicolumn{4}{|l|}{ Farm classification $(\%)$} \\
\hline Small & - & 24.00 & 72.73 \\
\hline Medium & - & 67.00 & 21.82 \\
\hline Large & - & 9.00 & 5.45 \\
\hline \multicolumn{4}{|l|}{ Occupation (\%) } \\
\hline Farming as primary & - & 73.00 & 80.91 \\
\hline Farming as secondary & 57.50 & 27.00 & 19.09 \\
\hline \multicolumn{4}{|l|}{ Average annual income (\%) } \\
\hline 50000-100000 BDT & - & 15.00 & 27.27 \\
\hline 1000001-250000 BDT & - & 72.00 & 67.28 \\
\hline 250001 and above BDT & 100.00 & 13.00 & 5.45 \\
\hline Average distance from home/mill to nearby market $(\mathrm{km})$ & 2.50 & 5.91 & 8.65 \\
\hline Average distance from home/mill to the procurement center $(\mathrm{km})$ & 3.70 & 14.04 & 17.62 \\
\hline $\begin{array}{l}\text { Average quantity of paddy produced by farmers and purchased by } \\
\text { millers in Boro season }(\mathrm{kg})\end{array}$ & 2354600.00 & 9290.00 & 4835.00 \\
\hline $\begin{array}{l}\text { Quantity of paddy/rice supplied to the procurement center in Boro } \\
\text { season }(\mathrm{kg})\end{array}$ & 202725.00 & 2084.00 & - \\
\hline Quantity of paddy/rice sold to the market in Boro season $(\mathrm{kg})$ & 1374852.00 & 4606.00 & 3152.00 \\
\hline Affiliate of any social organization (\%) & 73.00 & 70.0 & 16.36 \\
\hline Affiliate of any political organization (\%) & 79.00 & 67.0 & 31.81 \\
\hline
\end{tabular}

Note: Small farm (0.05-2.19 acre), medium farm (2.50-7.49 acre), and large farm (7.50 to above). This farm's classification has been obtained from BBS, 2018. 
and above, respectively. On the other hand, 27.00, 67.28, and 5.45 percent non-participant farmers were earning TK 50000-100000, TK 100001-250000, and TK 250001 and above, respectively. Whereas the average annual income was above TK 250001 for the millers.

The average distance from home/mill to the local market of the millers, participants, and non-participant farmers were 2.50, 5.90 and 8.65 kilometers, while the procurement center was 3.70, 14.04 and 17.62 kilometers away, respectively. The distance of the procurement center is more from the nonparticipant farmers' home than the local market. Therefore, distance of the procurement center can be a reason for not participating in the procurement programme. The millers are urban-centered to where they are not far from the market and procurement hub. Participants and non-participating farmers produced an average of 9.29 tons and 4.85 tons of paddy during the Boro season while millers purchased 2354.6 tons of paddy. Millers and participant farmers supplied at the government procurement center on average 202.73 and 2.0 tons of rice and paddy, respectively. In the Boro season, millers supplied 1374.85 tons of rice, and participant and non-participant farmers supplied 4.06 and 3.15 tons of paddy, respectively to the market. Non-participating farmers did not sell their paddy to the procurement hub because they had no procurement card, fewer details, and less expertise. A significant difference has been seen since farmers kept paddy for their family consumption and sold quantities among farmers. On the other side, millers process rice from the purchased paddy and usually obtained $25-28 \mathrm{~kg}$ rice from $40 \mathrm{~kg}$ paddy.

In general, respondents of this study were engaged as members of various social organizations, such as mosque committees, school boards, cooperative societies, farmer's field schools, professional associations, etc.
There are several political parties in Bangladesh, but four or five have been very prominent, getting certain kinds of suborganizations formed by various types of professionals such as teachers, students, service holders, farmers, businessmen, workers, bankers, and many others. In this study, the definition of the political organization's member is, in certain instances, the follower of governing or rulling political parties. About 79.0, 67.0 and 31.31 percent of the millers, participating farmers and nonparticipating farmers respectively, were members of different political groups.

\section{Farmers' and millers' perception}

Table 4 illustrated the farmers' view of the procurement system. About 56 percent of the participant and non-participant farmers agreed on the procurement price of Boro paddy (TK $24 / \mathrm{kg}$ ) to be reasonable during the survey. The procurement price was considered very low by the other 25 percent of respondents. About 52 percent said the volume of paddy fixed to procure from each farmer was sufficient. Almost a half of the farmers (48 percent) were happy with the scheduling of procurement. The majority of the respondents (48-63 percent) opined that the position of the procurement center and transportation to there are unpleasant to them. Very unfortunately, 58 percent of the respondents expressed that the procurement method is not corruption free. The respondents expressed that they had to pay unlawfully in cash and/or in kind for every quintal of paddy at the procurement centre. Nonetheless, 52 percent of farmers were not fully happy with the payment system for the procurement, whereas 44 percent of the respondents reported that the attitude of the officials was not nice towards the farmer. Approximately 65 percent farmers thought the procurement programme was inconvenient and had a chance to refuse to seller supply paddy at the procurement center. 
Table 4. Farmers' perception of government procurement programme.

\begin{tabular}{|c|c|c|c|c|c|}
\hline \multirow[b]{2}{*}{ Selected parameter } & \multicolumn{5}{|c|}{ Level of perception } \\
\hline & $\begin{array}{l}\text { Strongly } \\
\text { disagree }\end{array}$ & Disagree & Neutral & Agree & $\begin{array}{c}\text { Strongly } \\
\text { agree }\end{array}$ \\
\hline Paddy procurement price was reasonable & $4 \%$ ॥ा & $21 \%$ & $19 \%$ & $25 \%$ & $31 \%$ \\
\hline Quantity of paddy procured was reasonable & $11 \%$ & $29 \%$ & $8 \%$ & $42 \%$ & $10 \%$ \\
\hline Timing of paddy procurement was appropriate & $11 \%$ & $18 \%$ & $23 \%$ & $32 \%$ & $16 \%$ \\
\hline Procurement centers located at convenient distance & $14 \%$ & $32 \%$ 메 & $25 \%$ & $17 \%$ & $12 \%$ \\
\hline Transportation to procurement center is easy & $24 \%$ & $39 \%$ & $16 \%$ & $18 \%$ & $3 \% \|$ \\
\hline Procurement system is convenient & $21 \%$ & $52 \%$ & $7 \%$ & $20 \%$ & \\
\hline Mode of payment is appropriate & $13 \%$ & $39 \%$ & $3 \% \quad \mid$ & $45 \%$ & \\
\hline Behaviour of labour/officials with farmers is good & $5 \%$ & $39 \%$ & $8 \%$ & $48 \%$ & \\
\hline No undue dealings at the procurement center & $18 \%$ & $40 \%$ & $18 \%$ & $24 \%$ & \\
\hline Not rejected paddy at procurement center unfairly & $11 \%$ & $54 \%$ & $7 \%$ & $20 \%$ & $8 \%$ \\
\hline
\end{tabular}

Source: Prepared by authors using data from field survey 2018.

Table 5 summarizes millers perceptions regarding the rice procurement system. About 60 percent of the millers said that the procurement price (TK $34 / \mathrm{kg}$ ) of husked rice was relatively lower in 2018. Most of the millers (79 percent) expressed their satisfaction with the position and transportation to the procurement center as the mills were based on urban areas. Many millers (55 percent) were not happy with the procurement system while some of them (40 percent) acknowledged the system as reasonable. Almost 90 percent of millers said procurement system was not corruption-free and 75 percent expreseed that the behaviour of the procurement officials was not satisfying. On the other hand, Miller (57 percent) claims that when the rice was taken to the procurement center for selling, it was refused to take it without any reason.

Table 5. Miller's perception of the government procurement programme.

\begin{tabular}{|c|c|c|c|c|c|}
\hline \multirow[b]{2}{*}{ Selected parameter } & \multicolumn{5}{|c|}{ Level of perception } \\
\hline & $\begin{array}{l}\text { Strongly } \\
\text { disagree }\end{array}$ & Disagree & Neutral & Agree & $\begin{array}{c}\text { Strongly } \\
\text { agree }\end{array}$ \\
\hline Rice procurement price was reasonable & $10 \%$ & $50 \%$ & & $28 \%$ & $12 \%$ \\
\hline Quantity of rice procured was reasonable & $10 \%$ & $47 \%$ & $3 \%$ & $33 \%$ & $7 \%$ \\
\hline Timing of rice procurement was appropriate & $5 \%$ & $42 \%$ & $5 \%$ & $38 \%$ & $10 \%$ \\
\hline Procurement centers located at convenient distance & $10 \%$ 메 & $13 \%$ & & $48 \%$ & $29 \%$ \\
\hline Transportation to procurement center is easy & $8 \%$ & $8 \%$ IIII & $5 \%$ & $47 \%$ & $32 \%$ \\
\hline Procurement system is convenient & $10 \%$ & $45 \%$ & $5 \%$ & $33 \%$ & $7 \%$ \\
\hline Mode of payment is appropriate & $10 \%$ & $20 \%$ In⿴囗十) & & $50 \%$ & $20 \%$ \\
\hline Behavior of labour/officials with millers is good & $35 \%$ & $40 \%$ & & $20 \%$ & $5 \%$ \\
\hline No undue dealings at the procurement center & $50 \%$ & $40 \%$ & $3 \%$ & $5 \%$ & $2 \%$ \\
\hline Unfairly rejected rice at procurement center & $10 \%$ & $28 \%$ & $5 \%$ & $55 \%$ & $2 \%$ \\
\hline
\end{tabular}

Source: Prepared by authors using data from field survey 2018. 


\section{Production cost and procurement price of Boro paddy and rice}

Figure 1 presents the cost of production and the procurement price of paddy and rice per $\mathrm{kg}$ over the last 12 years. Despite a significant year to year fluctuation, both the cost of production and the procurement prices of paddy and rice have shown increasing trends. This implies a disparity between the rate of increase in the cost of production and the procurement price. The gap between the procurement price and the cost of production for rice in 2009 and paddy in 2013 decreased to the lowest, which suggests that millers and farmers earned lower returns. On the other hand, the price margin for rice in 2008 and paddy in 2015 rose to the highest, implying the higher returns for millers and farmers.

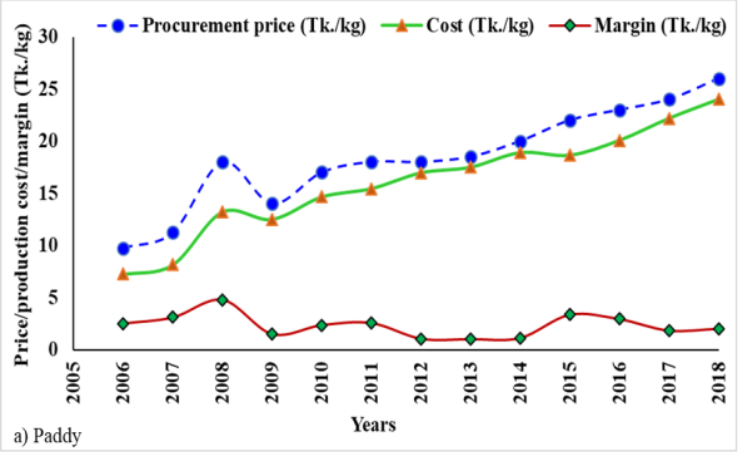

\section{Farmer's costs and returns}

How much current procurement programme supports the paddy price and income of farmers in achieving the target of this scheme, the evaluations needed were done, and Table 6 represent the relevant data. The findings indicate that farmers charged the marginally higher cost of selling paddy at the procurement center (Tk 295/ton) than the local market as they had to pay some money to the procurement scruples employees and higher transporting cost to the procurement center. Nevertheless, Tk 4,205 was the net profit of sales per ton of paddy at the procurement center and was far higher than the additional expense. This means that the participant farmers get a 22.16 percent higher return than the non-participant farmers by selling paddy at the procurement center.

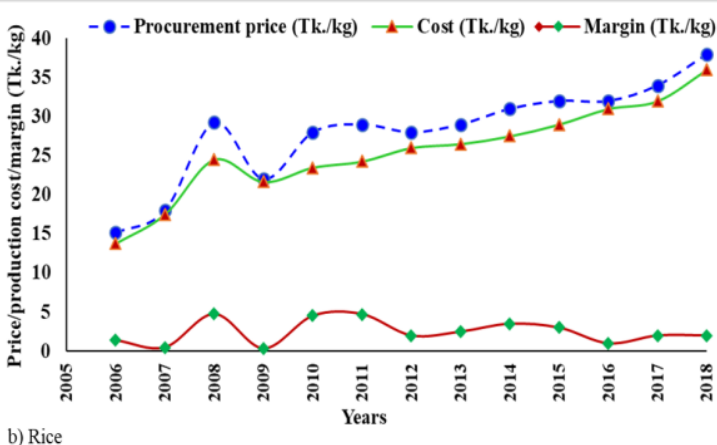

Fig. 1. Procurement price, production cost and margin of paddy and rice in Boro season. Source: Prepared by authors using data from field survey, Ministry of Food and Agricultural Economics Division, BRRI.

Table 6. Costs and return of supplying paddy to the procurement center and local market by farmers in 2018.

\begin{tabular}{lcc}
\hline Particular & \multicolumn{2}{c}{ Farmers paddy selling point } \\
\hline Paddy sold (ton/farm) & Procurement center & 2.08 \\
Gross return (Tk/ton) & $24,000.0$ & $19,500.0$ \\
Gross return (Tk/farm) & $49,920.0$ & $40,560.0$ \\
Cost of selling paddy (Tk/ton) & $8,20.0$ & $5,25.0$ \\
Total cost of selling (Tk/farm) & $1,705.6$ & $1,092.0$ \\
Net margin (Tk/farm) & $48,214.4$ & $39,468.0$ \\
Incremental margin of selling paddy (Tk/farm) & $8,746.4$ & - \\
Incremental margin of selling paddy (Tk/ton) & $4,205.0$ & - \\
\hline
\end{tabular}

Source: Analyzed and prepared by authors based on data from field survey. 


\section{Costs and returns at the millers' level}

Millers purchase paddy from farmers and traders, then mill it into rice and ultimately sell rice to the procurement center as per their fixed amount allotted. They are also engaged in crushing the paddy from procurement. The major cost items of supplying husked rice to the procurement center were the transportation of paddy from farm to mills and the processing. Besides, some undue payment to procurement staff was notable. Generally, clean rice can get up to 65 percent after paddy processing, with 35 percent by-products and waste (Singh et al. 2014). After processing, the survey millers get a total of 67 percent clean rice. At the miller's level net profit per ton of rice was Tk 3,930 (Table 7).

\section{Factors affecting farmers' participation in the paddy procurement programme}

Table 8 represents the results of the estimated binary probit model using the maximum likelihood method. The factors responsible for affecting the farmers' participation at the procurement center for selling paddy were analyzed, and the estimated coefficients and standard errors are depicted in the table. The results of the model indicate that some of the variables had significant effects on the probability of participating in the procurement programme and were in agreement with some of the findings of previous studies.

The empirical result showed that education is an important factor for the farmer in participating in the procurement programme. The marginal effect reveals the likelihood of the farmer's willingness to participate in the procurement programme increased by one percent with the increase of the level of farmers' schooling years. This indicated that the more educated the farmer is, the more willing they are to enroll in the government procurement programme, presumably because the educated farmers can handle information quicker than the others.

Table 7. Costs of and return for supplying rice to the procurement center at the miller's level in 2018.

\begin{tabular}{lc}
\hline Item & Taka (BDT.) \\
\hline Paddy purchasing cost & 19500.0 \\
Purchasing paddy from market (ton) & 330.0 \\
Cost of bagging and loading of paddy (ton) & 205.0 \\
Carrying cost of paddy to mill (ton) & 1185.0 \\
Paddy processing cost & 150.0 \\
Milling and bagging(ton) & 50.0 \\
Transportation cost to procurement center(ton) & 21420.0 \\
Miscellaneous cost(ton) & 2570.0 \\
Total cost (ton) & 22780.0 \\
Gains from by-product (ton) & 25350.0 \\
Price received from the procurement center (ton) & 3930.0 \\
Total return (ton) & \\
Net profit (ton) &
\end{tabular}

Note: Millers get $670 \mathrm{~kg}$ rice from 1ton paddy. Paddy was purchased @19.5 TK/ kg, and the price of cleaned rice at the procurement center was $34 \mathrm{TK} / \mathrm{kg}$. Source: Analyzed and prepared by authors using data from field survey. 
Table 8. Maximum likelihood estimates and marginal probability for the explanatory variables in the probit model $(n=210)$.

\begin{tabular}{|c|c|c|c|}
\hline Variable & Coefficient & Robust standard error & Marginal effect \\
\hline Constant & -1.43 & 1.79 & - \\
\hline Farmer's age & -0.01 & 0.01 & -0.001 \\
\hline Education & $0.17^{* * *}$ & 0.04 & $0.01^{* * *}$ \\
\hline Knowledge about procurement & $0.79^{* * *}$ & 0.18 & $0.07^{* * *}$ \\
\hline Marketed surplus & 0.00001 & 0.00003 & 0.0000001 \\
\hline Procurement price & $1.40^{* \star * *}$ & 0.40 & $0.12^{* * * *}$ \\
\hline Procurement card & $1.15^{* * *}$ & 0.41 & $0.10^{* * *}$ \\
\hline Procurement time & $1.28^{* * *}$ & 0.43 & $0.11^{* * *}$ \\
\hline Distance local market & -0.09 & 0.14 & -0.01 \\
\hline Distance from procurement center & $-0.29^{* *}$ & 0.13 & $-0.02^{* *}$ \\
\hline Communication system & $1.06^{* * *}$ & 0.38 & $0.09^{* * * t}$ \\
\hline Political affiliation & $0.81^{* *}$ & 0.41 & $0.07^{* *}$ \\
\hline Well manner of officials & $1.69^{* * *}$ & 0.41 & $0.14^{* * *}$ \\
\hline Corruption in the system & -0.26 & 0.35 & -0.02 \\
\hline Log pseudolikelihood & & -32.51 & \\
\hline Wald chi ${ }^{2}$ & & 103.90 & \\
\hline Prob $>\mathrm{chi}^{2}$ & & 0.0000 & \\
\hline Pseudo R ${ }^{2}$ & & 0.78 & \\
\hline
\end{tabular}

Note: $(* * *),(* *)$ denote significance at the $1 \%$, and $5 \%$ levels, respectively. Analyzed and prepared by authors based on data from field survey.

To determine the effects of knowledge about the procurement system on the likelihood of taking part in the procurement programme, the model included the knowledge level of farmers about the procurement system. As expected, the knowledge about the system has a positive and significant effect on participation in the procurement programme. The marginal effect estimation indicates that the probability of participation in the procurement programme would be increased by 7.0 percent in the study areas as knowledge grew. This result is consistent with the findings of the study by Alam et al. (2017).

The procurement price is one of the key factors that affect the participation decisions of farmers on the programme. The positive and significant coefficient for procurement price implies that the higher price attracted farmers to sell paddy at the procurement center instead of selling in the market. The marginal effect revealed that the probability of enrolment in the government procurement programme would increase by 12 percent if the procurement price were higher than the price that exists in the local market.

The farmers must need a procurement card to sell paddy at the procurement programme. The coefficient for having/ obtaining a procurement card was positive and significant which implies that the higher the chance of getting a procurement card, the greater the probability of the farmers 
selling paddy to the procurement programme. According to the model result, marginal effect estimation of the variable indicates that a one percent increase in having/obtaining the farmers' procurement card would increase the probability of participating in the procurement programme by $10 \%$.

Appropriate timing is also a significant consideration for the farmer's participation in the procurement system and shows a positive and significant coefficient. The results of the marginal effect also indicate that a one percent increase in the duration of procurement time would increase the participation of the farmers in the procurement programme by 11 percent in the surveyed areas.

Distance from home to the procurement center also an essential factor to attract farmers in the procurement programme. A negative and significant coefficient of marginal effects indicates that a one percent increasing in the distance from home to the procurement center would decrease the likelihood of farmers becoming interested in the participation of the procurement programme by two percent. A similar explanation has been drawn by Sabur et al. (2003).

In addition to distance, better communication facility plays a vital role to fetch the farmers in the procurement programme. The marginal effect of the communication system depicted that one percent increase in good connectivity between farmers home to the procurement center will increase the probability of being farmers' participation in the procurement programme by nine percent. Due to good connectivity farmers' have to incur lower transportation costs, which encourages them to sell paddy even in the long-distance procurement hubs.
Farmers who support a political party usually get the favour of selling paddy at the procurement center. The marginal effect estimation model results indicate that one percent increase in the affiliation with the political party will increase the probability of selling paddy at the government procurement programme by seven percent, which is similar to the findings of Alam et al. (2017).

The behaviour of the procurement center officials has a positive effect on farmers' participation in the procurement programme. Marginal effects show that one percent increase in good behaviour of the officials will increase the probability of farmers participating in the procurement programme by 14 percent in the respected study areas.

\section{Farmers perceived constraints of procurements systems}

An attempt was made to identify the reasons for not selling paddy by farmers to the procurement center. The major bottleneck of not selling paddy at the procurement center are as follows:

- Despite keeping the grain quality, most farmers are unable to sell paddy at the procurement center, as they are not meeting any unscrupulous undue demand of the officials at procurement center official. Farmers are therefore selling paddy at a cheaper price on the local market. However, the same quality paddy was purchased by the procurement center from local traders, as the traders give a certain percentage of the price as commission to the procurement workers.

- Usually, the paddy price on the day of purchase is not paid to the farmers. Therefore, farmers lose confidence in selling paddy at the procurement center, because they require money to satisfy their immediate needs. 
- Both the participant and non-participant farmers reported that the cost of transportation to carry the paddy to the procurement center is too high. This is due to the distance between the homes of the farmers and the procurement center.

- Farmers also stated that procurement workers are strongly biased in providing procurement card among the farmers. They mentioned that elite farmers and those who are politically aligned are given high priority to be enlisted as farmers in procurement. In fact, certain political or elite farmers sell a significant quantity of paddy at procurement centers by sanctioning procurement card named as neighbouring local farmers.

- The list of farmers in the procurement field is not frequently revised. The same farmers, therefore, take advantage of selling paddy at the procurement center.

- Access to sell paddy by tenant farmers at the procurement center is very restricted, as they were unable to display the land registration certificate. This is because the landlords usually do not supply a valid copy of the land registry to the tenants.

- The capacity of government procurement is very limited in Bangladesh. The government is procuring only 5-7 percent of the domestically produced paddy at a reasonable farmgate price (Rahman et al. 2020). The rest of the paddy is being purchased, processed and controlled by the private traders. Therefore, one of the procurement's main objectives is that ensuring a fair price for the producers' is not being achieved.

\section{CONCLUSION AND POLICY} RECOMMENDATIONS

This study focused on socio-economic and demographic factors affecting farmers' participation in the government procurement programme in the Nagaon and Mymensingh district of Bangladesh. We employed the binary probit model to examine the social and demographic variables. This research showed that the government procurement programme in Boro season has positive impacts on participant farmers and millers. The government paddy purchases as price support, and the demand from other agents push market prices up to favour the rice growers, who usually sell at a lower price during harvest. Through this scenario, the profit comes not just to the participating farmers but also to all growers. Aside from the farmers, millers also get profit by selling husked rice at the procurement center at a rate of $T k$ 3,930 per ton.

The findings of this research also showed the socio-economic features of the farmers influenced the decision to participate in the procurement programme. The results from the binomial probit model, education, knowledge about procurement, price, procurement card, procurement time, the distance of procurement center, communication system, political affiliation and good behaviour of the officials significantly influenced the participation in the procurement programme. Inadequate quota, anomalies of procurement staff, the undue expectation of scruples procurement staff, strict regulation about quality of paddy and husked rice and payment system, recognized as the drawback of procurement systems.

A well-functioning government paddy procurement system is critical for ensuring the country's food security and increasing farmers' income. The procurement policy implicitly benefits farmers by way of a market mechanism because market prices and procurement prices are positively related. Based on the findings, we outlined some specific recommendations for the improvement of the procurement programme-

- Almost all non-participating farmers indicated that they were not well informed 
about the public paddy/rice procurement programme's rules and regulations. Therefore, an awareness-raising campaign to build knowledge among farmers would increase their bargaining power, which could increase the involvement of farmers in the programme.

- To ensure the easy participation of farmers in the scheme, a community representative should be selected from village groups of farmers. This will help to have access to the procurement cards and adequate paddy share to sell at the procurement center regardless of the type and political affiliation.

- Forming a triangle link marketing system consisting of farmers, millers and government may ensure fare paddy price for the farmers. In this system, the government procurement price of paddy will be transferred directly to the farmers' 10 Taka bank account. Then, millers will collect the prescribed amount of paddy from the jurisdiction of the farmers. After that, millers will process rice through milling and supply clean rice to the government procurement center. The government will pay the milled rice price (considering the costs of parboiling and transportation) to millers directly. In this regard, a monitoring team can be formed at the upazila level for managing this programme efficiently.

- The capacity of the government procurement should be enlarged so that the system can procure a substantial amount of paddy that can influence the rice market to maintain a reasonable farmgate price of the paddy. In this way, the government procurement programme can make rice production profitable to increase the income of rice farmers.

- Besides, it is necessary to start procuring paddy/rice as early as possible after starting the harvest season. It will influence and increase the participation of the farmers in the procurement programme. It would also push market prices for the support of poor farmers, who normally sell paddy at a lower price during harvesting time.

If this is materialized, the country's rice production will boost up to sustain food security and farmers' income towards achieving the target of SDG.

\section{AUTHORS' CONTRIBUTION}

MSR planned and conceptualized the research, collected data, analyzed data and drafted the manuscript; MARS gave technical guidance, checked the research methods and provided an in-depth manuscript review; MJK provided guidance and comprehensive manuscript review; LD collected data and organized the field activities; MCR offered professional advice on the correct methodology and provided in depth manuscript review; MAI engaged in data analyzing; MABS provided considerable insight into the manuscript. All authors' perused and accepted the final manuscript.

\section{ACKNOWLEDGEMENTS}

The writers are indebted to the District Food Controller's office workers for supplying the list of growers and millers who participated in the procurement programme. We appreciate all the respondents who took part in the study too.

\section{DECLARATION OF INTERESTS}

Every author accepts and consents to the publishing of the manuscript. The authors declare having no conflicting interests.

\section{REFERENCE}

Ahmed, R and A Bernard. 1989. Rice price fluctuation and an approach to price stabilization in Bangladesh, research report Vol. 72, International Food Policy Research Institute, Washington DC., USA. 
Alam, M J, S Akter and I A Begum. 2015. Effectiveness of rice procurement programme and the determinants of the farm level stocks of rice in Bangladesh. Proceeding of IAAE Congress, Milan, Italy, August 8-14.

Alam, M J, S Akter, I A Begum and M M Haque. 2020. Determinants of the farm-level stocks of rice and effectiveness of rice procurement programme in Bangladesh. Journal of the Asia Pacific Economy, 26:1, 116-139. DOI: $10.1080 / 13547860.2020 .1722559$

Alam, S, S Haque, S Islam, A Jannat, and M M Islam. 2017. Feasibility of rice procurement programme for poor farmers in Bangladesh. Progressive Agriculture, 28(2):139-147.

Aldrich, J H and F D Nelson. 1984. Linear probability, logit and probit model: Quantitative application in the social science (No. 45). Sara Miller McCune. Sage Publications Inc, Newbury Park, California, USA.

BBS (Bangladesh Bureau of Statistics). 2018. Statistical yearbook of Bangladesh. Statistics and Informatics Division, Bangladesh Bureau of Statistics, Ministry of Planning, Government of the People's Republic of Bangladesh, Dhaka, Bangladesh.

BBS (Bangladesh Bureau of Statistics). 2019. Yearbook of Agricultural Statistics. Statistics and Informatics Division, Bangladesh Bureau of Statistics, Ministry of Planning, Government of the People's Republic of Bangladesh, Dhaka, Bangladesh.

BER (Bangladesh Economic Review). 2018. Bangladesh economic review. Economic adviser's wing, Finance Division, Ministry of Finance, Government of the People's Republic of Bangladesh, December 2018, Dhaka, Bangladesh.

BRRI (Bangladesh Rice Research Institute). 2017. Annual report of Agricultural Economics Division, 20162017, Bangladesh Rice Research Institute (BRRI), Gazipur 1701, Bangladesh.

Deb, U K. 2008. Boro procurement and food security strategy: an actionable agenda. in keynote presentation at a seminar organized by Centre for Policy Dialogue on (Vol. 21), April 2008, Dhaka Bangladesh.

Dorosh, P A and Q Shahabuddin. 2002. Rice price stabilization in Bangladesh: An analysis of policy options. Markets and structural studies division, Discussion paper No. 46. International Food Policy and Research Institute (IFPRI). Washington DC.

Greene, W H. 2011. Econometric analysis. Prentice Hall, 7th Edition edition.

HIES (Household Income and Expenditure Survey). 2016. Final report on household income and expenditure survey. Bangladesh Bureau of Statistics, Statistics and Information Division, Ministry of Planning, Government of the People's Republic of Bangladesh, Dhaka, Bangladesh.
MoF (Ministry of Food). 2017. Internal Foodgrain Collecting Policy, Ministry of Food (MoF), People's Republic of the Government of Bangladesh, Dhaka, Bangladesh.

MoA (Ministry of Agriculture). 2019. Annual report 20182019. Ministry of Agriculture (MoA), Government of the People's Republic of Bangladesh, October 2019, Dhaka, Bangladesh.

Rahman, M C, V Pede, J Balie, I Pabuayon, J Yorobe and S Mohanty. 2020. Assessing the Market Power of Millers and Wholesalers in the Bangladesh Rice Sector. Journal of Agribusiness in Developing and Emerging Economies. DOI: 10.1108/JADEE-04-2018-0053.

Reza, M S. 2001. An evaluation of government Boro rice procurement in selected areas of Bogura and Naogaon districts. An unpublished MS thesis submitted to the Department of Agribusiness and Marketing, Bangladesh Agricultural University, Mymensingh, Bangladesh.

Sabur, S A, H Jahan and M S Reza. 2003. An evaluation of government rice procurement programme in selected areas of Bangladesh. Bangladesh Journal of Agricultural Economics, 26(454-2016-36528), 111-126.

Sattar, M S. 2011. An economic evaluation of public food operations in Bangladesh with special emphasis on government rice procurement rice and paddy procurement programmes. An unpublished MS thesis submitted to the Department of Agricultural Economics, Bangladesh Agricultural University, Mymensingh, Bangladesh.

Shahabuddin, Q and K M N Islam. 1999. Domestic rice procurement programme in Bangladesh-An evaluation. Food management and research support project, Dhaka, Bangladesh.

Shahabuddin, Q and S Shahana. 2014. Achievements, challenges, and prospects of food security: context Bangladesh. Bangladesh Unnayan Shamikkhaya, Bangladesh Institute of Development Studies, Vol. 32, 2014, Dhaka, Bangladesh, pp 37-66.

Shahabuddin, Q, M Asaduzzaman, E Clay and S Jones. 2009. Price support, domestic procurement programme, and public stock management. BIDS Policy Brief, Dhaka, Bangladesh.

Singh, A, M Das, S Bal and R Banerjee. 2014. Rice processing. Engineering aspects of cereal and cerealbased products. CRC Press, Taylor \& Francis Group, Boca Raton Florida, USA, pp. 71-96.

Uzunoz, M and Y Akcay. 2012. A case study of probit model analysis of factors affecting consumption of packed and unpacked milk in Turkey. Economics Research International, vol. 2012, Article ID732583, 8 pages, 2012. https://doi.org/10.1155/2012/732583. 